\title{
Acute poststreptococcal glomerulonephritis in Maracaibo. II: Studies on the incidence, nature, and significance of circulating anti-immunoglobulins
}

\author{
RAWLE M. MCINTOSH, DANA RABIDEAU, JAMES E. ALLEN, \\ RAFAEL GARCIA, LIRIMO RUBIO, RONALD I. CARR, AND \\ BER NARDO RODRIGUEZ-ITURBE
}

From the Divisions of Nephrology, Clinical Immunology, and Infectious Diseases, University of Colorado Medical Center, Denver, Colorado, the National Jewish Hospital and Research Center, Denver, Colorado, and the Renal Service, Department of Medicine, Hospital Universitario, and Universidad del Zulia, Maracaibo, Venezuela

SUMMARY Antiglobulins were measured in the sera of 82 patients with acute poststreptococcal glomerulonephritis and correlated with $\mathrm{Clq}$ binding activity, serum levels of immunoglobulins and C3, site of infection, antibody titres to streptococcal enzymes, and the duration of the nephritis and interval from infection. Raised serum antiglobulins were found in $89.2 \%$ of the patients. In addition, raised titres were detected at any time during the course of the disease and very early after streptococcal infection. The finding of antiglobulins soon after the infection suggests the possibility that they appear as a primary event in the disease.

Several mechanisms have been proposed for the immune renal injury following infection with certain strains of 'group A $\beta$ haemolytic streptococcus (Zabriskie et al., 1973). Even though many morphological, clinical, and serological features strongly suggest that acute poststreptococcal glomerulonephritis (APSGN) is an immune complex disease, the precise nature of the antigen-antibody system(s) operating in the disease remains undefined (Michael et al., 1966; Lange and Treser, 1973; Zabriskie et al., 1973). The evidence suggest that antibody reacting with streptococcal antigen(s) in the circulation or locally in the glomerulus incites renal inflammatory disease (Michael et al., 1966; Lange and Treser, 1973; McCluskey and Klassen, 1973; Zabriskie et al., 1973).

From a series of clinical and laboratory observations in man and experimental animals we proposed that autologous immune complex systems may be of primary or secondary immunopathogenic significance in renal disease related to streptococcal infection (McIntosh et al., 1970; McIntosh et al., 1971 a, 1971b; McIntosh et al., 1972; McIntosh et al.,

Accepted for publication 12 June 1978

Correspondence to Professor Rawle M. McIntosh, University of Colarado Medical Center, Box C282, 4200 E 9th Avenue, Denver, Colorado 80262, USA.
1975; Griswold et al., 1975). In this postulated mechanism, immunoglobulins are rendered autoimmunogenic by modification or interaction with streptococcal products or by incorporation into an immune complex. Antibodies formed to this neoautoimmunogen combine with the neoantigen forming pathogenic immune complexes. This antigenantibody interaction may occur in the circulation or in situ in the renal glomerulus.

\section{Patients and methods}

Studies were performed on 82 patients admitted to the Hospital Universitario of Maracaibo, Venezuela, for evaluation of acute glomerulonephritis. The age of the patients ranged between 2 and 37 years; $38 \%$ were less than 7 years of age, $50 \%$ between 7 and 15 years, and $12 \%$ older than 15 years. All patients presented with an acute nephritic syndrome (acute onset of haematuria, urinary red blood cell casts, hypertension, oedema) without concurrent systemic disease. There was evidence of antecedent streptococcal infection in all patients. The renal disease was preceded by skin infection in 45 patients, pharyngeal in 20, and both skin and pharyngeal in 5 . The site of infection was unknown in 12 patients. The approximate time of onset of clinical mani- 
festations of infection was known in 64 patients. Serum antibody titres to 1 or more streptococcal enzymes were raised in all but 1 patient.

Careful histories, serial complete physical examinations, assessment of clinical status and renal function, and routine serology were obtained in all patients. In addition, serum was obtained for special studies.

\section{SERUM STUDIES}

A single serum sample was obtained from each patient during the course of admission to hospital for the special immunological studies. The sample was obtained as early as the day of onset of the first sign or symptom of renal disease and up to 30 days after the onset of clinical evidence of nephritis. The interval between the reported date of the first signs or symptoms of infection and the obtaining of serum samples for special study varied between 2 and 8 weeks.

The serum sample from each patient was immediately frozen and stored at $-70^{\circ} \mathrm{C}$ prior to testing. Levels of immunoglobulin $\mathbf{G}, \mathbf{M}$, and $\mathbf{A}$, as well as $\mathrm{C} 3$ were quantitated by radial immunodiffusion. Titres of antistreptolysin 0 (ASO), antihyaluronidase $(\mathrm{AH})$, and streptozyme were determined. Immune complexes were measured by the C1q binding assay of Zubler et al. (1976) using ${ }^{125} \mathrm{I} \mathrm{Clq}$ and polyethylene glycol. The method of $\mathrm{Clq}$ determination and the Clq binding activity in these patients are detailed in another communication (Rodriguez-Iturbe et al., 1978). C1q was isolated from normal serum radiolabelled with ${ }^{125} \mathrm{I}$ and reacted with the test sera. Separation of free from complex bound ${ }^{125} \mathrm{I} \mathrm{Clq}$ was achieved by selective precipitation with polyethylene glycol. Clq binding activity (ClqBA) was calculated as percent of ${ }^{125} \mathrm{I}$ $\mathrm{Clq}$ precipitated. All samples were tested in duplicate. Serum samples from apparently normal healthy individuals were included on each test run.

The procedure was also performed reacting ${ }^{125} \mathrm{I}$ Clq with varying amounts of aggregated IgG (aggregated by heat and precipitation with $\mathrm{Na}_{2} \mathrm{SO}_{4}$ ). ClqBA was measured in over 100 apparently healthy subjects. The mean binding obtained was $9 \cdot 5 \pm 2 \cdot 6$. Therefore the mean +2 SD was $14 \cdot 7$, and in our laboratories C1q greater than $15 \%$ is considered abnormal. Antiglobulin titres were determined by agglutination using IgG coated latex particles. In selected samples anti-IgG was isolated by elution from immunoabsorbents: gluteraldehyde cross-linked human IgG, and IgG coupled to cyanogen bromide activated sepharose (Miller et al., 1977).

The isolated antiglobulin was characterised by double inmunodiffusion in agar gel using rabbit antisera to human IgG, IgM, IgA, and albumin. Thẹ eluate was further characterised by Sephadex G $20 \mathrm{Q}$ gel filtration and polyacrylamide gel electrophoresis? The IgG used in the immunoabsorbent studies was prepared from normal human serum by ammoniun: sulphate precipitation, ion exchange chromato graphy on diethyl-aminoethyl cellulose, and Sepha@ dex G 200 gel filtration. The serum used was ob tained from apparently healthy individuals with $n g$ recent illness and normal physical examination; urine analysis, and glomerular filtration rate. Theे donor sera had no detectable anti-IgG activity negative antistreptolysin 0 (ASO), and antihya luronidase $(\mathrm{AH})$ titres, no $\mathrm{ClqBA}$, and normal levelso of serum $\operatorname{IgG}, \operatorname{IgM}, \operatorname{IgA}$, and $\mathrm{C} 3$.

\section{Results}

The serological findings of the patients are sum= marised in Table 1. The distribution of antiglobulin titres is illustrated in Table 2. Rheumatoid factor titres were greater than $1: 32$ in $89.2 \%$ of patients $\overrightarrow{6}$ Levels exceeding 1:256 were found in $64.6 \%$ and titres as high as 1:4096 were found in $8.5 \%$. Im munoabsorbent studies revealed anti-IgG activity in both IgM and IgG classes. No IgA was detected in the materials tested. There was no relationshiz between age or sex of the patients, the site of infection, or the levels of antibody titres to strepto coccal antigens. Although correlation could not be

Table 1 Summary of serological findings in acute poststreptococcal glomerulonephritis

\begin{tabular}{|c|c|c|c|}
\hline & $\begin{array}{l}\text { Number of } \\
\text { patients }\end{array}$ & $\%$ Positive & $\begin{array}{l}\text { Total number } \\
\text { patients studiea }\end{array}$ \\
\hline $\begin{array}{ll}\uparrow \text { anti-streptococcal } \mathrm{Ab}^{*} \\
\uparrow \mathrm{IgG}(1600 \mathrm{mg} / 100 \mathrm{ml}) \\
\uparrow \mathrm{IgM}(150 \mathrm{mg} / 100 \mathrm{ml}) \\
\uparrow \mathrm{IgA}(300 \mathrm{mg} / 100 \mathrm{ml}) \\
\uparrow \mathrm{C3}(100 \mathrm{mg} / 100 \mathrm{ml}) \\
\uparrow \mathrm{ClqBA}(15 \%)\end{array}$ & $\begin{array}{l}81 \\
68 \\
77 \\
21 \\
65 \\
45\end{array}$ & $\begin{array}{l}98 \cdot 8 \\
93 \cdot 2 \\
98 \cdot 7 \\
26 \cdot 9 \\
85 \cdot 5 \\
55 \cdot 5\end{array}$ & $\begin{array}{l}82 \\
73 \\
78 \\
78 \\
76 \\
70\end{array}$ \\
\hline
\end{tabular}

* Streptozyme, anti-streptolysin $\mathrm{O}$, anti-hyaluronidase, or combination $\mathrm{ClqBA}=\mathrm{Clq}$ binding activity.

Table 2 Incidence of rheumatoid factor in acute poststreptococcal glomerulonephritis

\begin{tabular}{|c|c|c|}
\hline $\begin{array}{l}\text { Rheumatoid } \\
\text { factor titres }\end{array}$ & $\begin{array}{l}\text { Number of } \\
\text { patients }\end{array}$ & $\%$ \\
\hline $\begin{array}{l}1: 8 \\
1: 16 \\
1: 32 \\
1: 64 \\
1: 128 \\
1: 256 \\
1: 512 \\
1: 1024 \\
1: 2048 \\
1: 4096\end{array}$ & $\begin{array}{r}2 \\
3 \\
9 \\
10 \\
5 \\
10 \\
11 \\
20 \\
5 \\
7\end{array}$ & $\begin{array}{r}2 \cdot 4 \\
3 \cdot 6 \\
10 \cdot 9 \\
12 \cdot 2 \\
6 \cdot 1 \\
12 \cdot 2 \\
13 \cdot 4 \\
24 \cdot 4 \\
6 \cdot 1 \\
8 \cdot 5\end{array}$ \\
\hline
\end{tabular}


made between the titres of antiglobulins and the interval between the onset of infection or nephritis (Tables 3 and 4), very high titres of rheumatoid factor were observed quite early. Of 10 cases studied less than 2 weeks after the streptococcal infection, seven had titres above $1: 256$. Similarly, 33 of 38 patients had titres greater than 1:256 within the first week of onset of symptoms.

There was no apparent association between rheumatoid factor titres and serum levels of immunoglobulins (Table 5). Similarly there was no apparent

Table 3 Rheumatoid factor in relation to time of onset of symptoms of nephritis

\begin{tabular}{|c|c|c|c|c|}
\hline \multirow{2}{*}{$\begin{array}{l}\text { Rheumatoid } \\
\text { factor titres }\end{array}$} & \multirow[b]{2}{*}{$0-7$} & \multicolumn{2}{|c|}{-Time (days) } & \multirow[b]{2}{*}{$>21$} \\
\hline & & $8-14$ & $15-21$ & \\
\hline $1: 8$ & 2 & 0 & 0 & $\mathbf{0}$ \\
\hline $1: 16$ & 2 & 0 & 1 & $\mathbf{0}$ \\
\hline $1: 32$ & 4 & 5 & $\mathbf{0}$ & 0 \\
\hline $1: 64$ & 5 & 5 & 0 & 0 \\
\hline $1: 128$ & 2 & 2 & 1 & 0 \\
\hline $1: 256$ & 5 & 2 & 1 & 1 \\
\hline $1: 512$ & 5 & 4 & 2 & 0 \\
\hline $1: 1024$ & 10 & 8 & 1 & 0 \\
\hline $1: 2048$ & 1 & 2 & 2 & 0 \\
\hline $1: 4096$ & 2 & 3 & 1 & 1 \\
\hline
\end{tabular}

Table 4 Rheumatoid factor in relation to time elapsed from streptococcal infection

\begin{tabular}{lcccc}
\hline $\begin{array}{l}\text { Rheumatoid } \\
\text { factor titres }\end{array}$ & $<2$ & $2-4$ & $4-6$ & $>6$ \\
\hline $1: 8$ & 0 & 1 & 0 & 1 \\
$1: 16$ & 0 & 1 & 2 & 0 \\
$1: 32$ & 2 & 4 & 1 & 0 \\
$1: 64$ & 1 & 1 & 6 & 1 \\
$1: 128$ & 0 & 3 & 1 & 0 \\
$1: 256$ & 0 & 1 & 3 & 0 \\
$1: 512$ & 1 & 6 & 3 & 0 \\
$1: 1024$ & 4 & 7 & 5 & 0 \\
$1: 2048$ & 2 & 1 & 1 & 0 \\
$1: 4096$ & 0 & 4 & 1 & 0 \\
\hline
\end{tabular}

relationship between $\mathrm{ClqBA}$ or $\mathrm{C} 3$ levels and rheumatoid factor titres (Table 6).

\section{Discussion}

Most observers agree that poststreptococcal glomerulonephritis is the result of immune complex injury to the renal glomerulus. Several streptococcal products have been implicated as the putative antigen in the pathogenic immune complexes (Seegal et al., 1965; Yoshizawa et al., 1973; Zabriskie et al., 1973; Treser et al., 1974; Lange et al., 1976). The inconsistency of demonstration of these antigens in the kidney and the failure to localise them along IgG in the subepithelial 'humps', as well as the inability to detect streptococcal antigen and antibody simultaneously in the cryoprecipitable complexes (McIntosh et al., 1971a), has led to the suggestion that alternative or additional immune complex systems may be involved.

We have reported cryoprecipitates containing IgM antibody and IgG antigen in poststreptococcal glomerulonephritis (McIntosh et al., 1970, 1971a, 1975). In one instance the IgG component lacked sialic acid, raising the possibility that the $\mathrm{IgG}$ fraction was an antigen rendered autoimmunogenic by absence of sialic acid (McIntosh et al., 1971a). Zinneman et al. (1968) studied the cryoprotein of a patient with IgM-IgG cryoglobulinaemia in which the IgG component of the cryoprotein lacked sialic acid. The IgM fraction possessed anti-IgG activity and gave a stronger reaction with neuraminidasetreated (sialic acid-depleted) IgG than with normal unmodified IgG. The IgM portion of the cryoglobulin fixed to the glomeruli of patients with chronic glomerulonephritis. Davis et al. (1977) found that 14 out of 120 strains of group A streptococcus produced neuraminidase. We have demonstrated decrease in the sialic acid content of human

Table 5 Rheumatoid factor titres in relation to serum immunoglobulin levels

\begin{tabular}{|c|c|c|c|c|c|c|c|c|c|c|c|c|}
\hline \multirow{2}{*}{$\begin{array}{l}\text { Immunoglobulin } \\
\text { class }\end{array}$} & \multirow{2}{*}{$\begin{array}{l}\text { Serum concentration } \\
(\mathrm{mg} / 100 \mathrm{ml})\end{array}$} & \multirow{2}{*}{$\begin{array}{l}\text { Total } \\
\text { patients }\end{array}$} & \multicolumn{10}{|c|}{ Rheumatoid factor titres } \\
\hline & & & $1: 8$ & $1: 16$ & $1: 32$ & $1: 64$ & $1: 128$ & $1: 256$ & $1: 512$ & $1: 1024$ & $1: 2048$ & $1: 4096$ \\
\hline IgG & $\begin{array}{r}>2400 \\
2000-2400 \\
1600-2000 \\
1000-1600 \\
<1000\end{array}$ & $\begin{array}{r}51 \\
17 \\
2 \\
3 \\
2\end{array}$ & $\begin{array}{l}0 \\
1 \\
1 \\
0 \\
0\end{array}$ & $\begin{array}{l}2 \\
1 \\
0 \\
0 \\
0\end{array}$ & $\begin{array}{l}5 \\
2 \\
0 \\
0 \\
0\end{array}$ & $\begin{array}{l}7 \\
2 \\
0 \\
1 \\
0\end{array}$ & $\begin{array}{l}4 \\
0 \\
1 \\
0 \\
0\end{array}$ & $\begin{array}{l}6 \\
3 \\
0 \\
0 \\
0\end{array}$ & $\begin{array}{l}8 \\
2 \\
0 \\
0 \\
0\end{array}$ & $\begin{array}{l}9 \\
5 \\
0 \\
1 \\
2\end{array}$ & $\begin{array}{l}4 \\
1 \\
0 \\
0 \\
0\end{array}$ & $\begin{array}{l}6 \\
0 \\
0 \\
1 \\
0\end{array}$ \\
\hline JgM & $\begin{array}{r}>450 \\
301-450 \\
151-300 \\
<150\end{array}$ & $\begin{array}{r}6 \\
53 \\
18 \\
1\end{array}$ & $\begin{array}{l}1 \\
0 \\
1 \\
0\end{array}$ & $\begin{array}{l}0 \\
3 \\
0 \\
0\end{array}$ & $\begin{array}{l}0 \\
5 \\
3 \\
0\end{array}$ & $\begin{array}{l}1 \\
8 \\
1 \\
0\end{array}$ & $\begin{array}{l}1 \\
3 \\
1 \\
0\end{array}$ & $\begin{array}{l}1 \\
7 \\
1 \\
0\end{array}$ & $\begin{array}{l}0 \\
6 \\
5 \\
0\end{array}$ & $\begin{array}{r}1 \\
14 \\
3 \\
0\end{array}$ & $\begin{array}{l}0 \\
3 \\
2 \\
0\end{array}$ & $\begin{array}{l}1 \\
4 \\
1 \\
1\end{array}$ \\
\hline IgA & $\begin{array}{r}>400 \\
301-400 \\
200-300 \\
<200\end{array}$ & $\begin{array}{r}3 \\
18 \\
40 \\
17\end{array}$ & $\begin{array}{l}0 \\
0 \\
0 \\
2\end{array}$ & $\begin{array}{l}0 \\
0 \\
1 \\
2\end{array}$ & $\begin{array}{l}0 \\
3 \\
3 \\
2\end{array}$ & $\begin{array}{l}0 \\
3 \\
5 \\
2\end{array}$ & $\begin{array}{l}0 \\
1 \\
4 \\
0\end{array}$ & $\begin{array}{l}0 \\
3 \\
4 \\
2\end{array}$ & $\begin{array}{l}0 \\
2 \\
6 \\
3\end{array}$ & $\begin{array}{l}1 \\
5 \\
9 \\
3\end{array}$ & $\begin{array}{l}1 \\
0 \\
3 \\
1\end{array}$ & $\begin{array}{l}1 \\
1 \\
5 \\
0\end{array}$ \\
\hline
\end{tabular}


Table 6 Rheumatoid factor titres in relation to serum Clq binding activity and C3 levels

\begin{tabular}{|c|c|c|c|c|c|c|c|c|c|c|c|c|}
\hline & & \multirow{2}{*}{$\begin{array}{l}\text { Total } \\
\text { patients }\end{array}$} & \multicolumn{10}{|c|}{ Rheumatoid factor titres } \\
\hline & & & $1: 8$ & $1: 16$ & $1: 32$ & $1: 64$ & $1: 128$ & $1: 256$ & $1: 512$ & $1: 1024$ & $1: 2048$ & $1: 40 \frac{96}{0}$ \\
\hline ClqBA (\%) & $\begin{array}{r}<15 \\
>15-20 \\
>20-30 \\
>30\end{array}$ & $\begin{array}{r}32 \\
35 \\
7 \\
3\end{array}$ & $\begin{array}{l}1 \\
0 \\
1 \\
0\end{array}$ & $\begin{array}{l}0 \\
3 \\
0 \\
0\end{array}$ & $\begin{array}{l}2 \\
5 \\
0 \\
1\end{array}$ & $\begin{array}{l}4 \\
3 \\
1 \\
2\end{array}$ & $\begin{array}{l}1 \\
3 \\
1 \\
0\end{array}$ & $\begin{array}{l}8 \\
1 \\
1 \\
0\end{array}$ & $\begin{array}{l}6 \\
5 \\
0 \\
0\end{array}$ & $\begin{array}{r}9 \\
10 \\
0 \\
0\end{array}$ & $\begin{array}{l}2 \\
2 \\
1 \\
0\end{array}$ & $\begin{array}{l}2 \\
3 \\
2 \\
0\end{array}$ \\
\hline $\begin{array}{l}\mathrm{C3} \\
(\mathrm{mg} / 100 \mathrm{ml})\end{array}$ & $\begin{array}{r}<40 \\
>40-70 \\
>70-100 \\
>100\end{array}$ & $\begin{array}{r}44 \\
12 \\
9 \\
11\end{array}$ & $\begin{array}{l}1 \\
1 \\
0 \\
0\end{array}$ & $\begin{array}{l}2 \\
0 \\
1 \\
0\end{array}$ & $\begin{array}{l}4 \\
0 \\
1 \\
3\end{array}$ & $\begin{array}{l}6 \\
2 \\
2 \\
0\end{array}$ & $\begin{array}{l}3 \\
2 \\
0 \\
0\end{array}$ & $\begin{array}{l}4 \\
1 \\
2 \\
2\end{array}$ & $\begin{array}{l}6 \\
4 \\
1 \\
0\end{array}$ & $\begin{array}{r}10 \\
1 \\
1 \\
4\end{array}$ & $\begin{array}{l}2 \\
1 \\
0 \\
2\end{array}$ & $\begin{array}{l}6 \\
0 \\
1 \\
0\end{array}$ \\
\hline
\end{tabular}

IgG incubated with a culture of nephritogenic streptococcus (McIntosh et al., 1971b). At least partial immunological identity between IgG modified in this manner and normal IgG was demonstrated.

Anecdotal reports from Eastern Europe claim early observation of rises of serum and urinary levels of neuraminic acid in patients with acute poststreptococcal glomerulonephritis. Autologous IgG modified by incubation with streptococci is capable of inducing cryoglobulins and glomerular IgG and C3 deposition in the rabbit, in the absence of steptococcal antigens, infection, or antistreptococcal antibodies (McIntosh et al., 1972). These findings suggest that streptococci induce an antiglobulin response like that seen in cryoglobulinaemia, which, interestingly, is a feature of APSGN. Streptococcal vaccine has also been reported to induce monoclonal antibody responses with anti-IgG activity and production of cryoglobulins (Sheagren et al., 1970).

Immune deposit disease characterised by granular glomerular accumulation of immunoglobulin G, C3, and fibrinogen, as well as circulating anti-IgG antibodies, was produced in inbred rats from injection of homologous IgG treated with costridial and influenzal neuraminidase and, to a less extent, neuraminidase alone.

In the present study antiglobulins were detected in the sera of the majority of patients with APSGN. The origin of these antiglobulins and their role in development and/or progression of glomerulonephritis is speculative, but in the context of the rest of available evidence it may be suggested that the antibodies may develop against IgG altered by streptococcal enzymes or IgG incorporated in immune complexes of streptococcal antigen and antibody. These autoantibodies may react with the neoantigen in the circulation or in the glomerulus. Since there is cross-reactivity with normal IgG, the antibody could also react with unmodified IgG in the circulation. However, in this instance the situation would be one of extreme antigen excess.

It is noteworthy that titres of rheumatoid factor were consistently raised independently of the duration of symptoms before the study, appearin in some cases within 8 days after the infection ando on the first day of symptoms of nephritis. This observation differs from those of immune comple nephritis associated with subacute bacterial endoo carditis (Bokish et al., 1972) and suggests that the production of antiglobulins may have occurred as a primary event rather than as antibody to $\operatorname{Ig}$ incorporated in an exogenous immune complex.

Immunoglobulin complexes (IgG-IgM, IgG-IgG $\overrightarrow{20}$ etc.) have been implicated in the pathogenesis of the renal lesion in systemic lupus erythematosus (Agnello et al., 1973), progressive systemic sclerosi₹ (McCoy et al., 1976), and essential cryoglobulin aemia (Golde and Epstein, 1968). It is of interesf that ultrastructural studies of glomeruli of somg patients with IgM-anti-IgG cryoglobulinaemia have shown subepithelial humps indistinguishable frong those observed in APSGN (Skrifvars et al., 1973).

Glomerular-fixed antiglobulins have been found it some patients with nephritis of various aetiologies (Rossen et al., 1977). These antiglobulins may have different properties from those found in rheumatoi arthritis. It has been suggested that antiglobulins may bind to immune complexes in the circulation diverting the immune complex from the renal glomerulus (Lightfoot et al., 1969), a suggestioß borne out by the infrequency of development of glomerulonephritis in patients with rheumatoi\&. arthritis. In fact soluble immune complexes are frequently found in the sera of these patients (Zubler et al., 1976). It is possible that poststreptococcan glomerulonephritis involves a variety of immunes complex systems with exogenous, as well as ende genous, immune complexes, antigen-antibody intero actions occurring both in the circulation and localls (in situ) in the kidney, a situation analogous to that of the nephritis of systemic lupus erythematosusp (Agnello et al., 1973).

Serial determinations of antiglobulins and cor relations with clinical serological and immuno $\mathbb{R}$ logical parameters may provide insight into the factors determining the development and progressio 
of renal disease associated with streptococcal infection.

Supported by CONICIT Grant No. S4-141 (Venezuela), grant from the Asociacion de Amigos del Rinon (Maracaibo), grants in aid from the American Heart Association, Colorado Heart Association, United States Public Health Service Grants 5S01 RR 05357, GCR RR 69, RR0051, AMO 7135, and T3280 107028, and grant in aid from the Rocky Mountain Foundation. Part of this work was performed during the tenure of an established investigatorship from the American Heart Association (Dr McIntosh).

\section{References}

Agnello, V., Koffler, D., and Kunkel, H. G. (1973). Immune complex systems in the nephritis of systemic lupus erythematosus. Kidney International, 3, 90-99.

Bokish, V. A., Bernstein, D., and Krause, R. M. (1972). Occurrence of $19 \mathrm{~S}$ and $7 \mathrm{~S}$ anti-IgGs during hyperimmunization of rabbits with streptococci. Journal of Experimental Medicine, 136, 799-895.

Davis, L. E., Baig, M. M., and Ayoub, E. M. (1977). Sialidase production by group A streptococci. Annual Meeting of the American Society of Microbiology, p. 207 (abstract).

Golde, D., and Epstein, W. (1968). Mixed cryoglobulins and glomerulonephritis. Annals of Internal Medicine, 69, 1221-1227.

Griswold, W. R., McIntosh, J. R., Weil, R., and McIntosh, R. M. (1975). Neuraminidase treated homologous IgG and immune deposit renal disease in inbred rats. Proceedings of the Society for Experimental Biology and Medicine, 58, 382-387.

Lange, K., Treser, G., Ahmed, U., and Sagel, I. (1976). Antibody titers to a recently identified antigen related to streptococcal glomerulonephritis. Kidney International, 10, 546 (abstract).

Lange, K., and Treser, G. (1973). Glomerulonephritis: mechanisms and sequelae. Attempts at a unifying concept. Clinical Nephrology, 1, 55-60.

Lightfoot, R. W., Drusin, R. E., and Christian, C. L. (1969). Interaction of soluble immune complexes with rheumatoid factors. Annals of the New York Academy of Sciences, 168, 105-110.

McCoy, R. C., Tisher, C. C., Pepe, P. H., and Cleveland, L. A. (1976). The kidney in progressive systemic sclerosis: Immunohistochemical and antibody elution studies. Laboratory Investigation, 35, 124-130.

McCluskey, R. T., Klassen, J. (1973). Immunologically mediated glomerular, tubular and interstitial renal disease. New England Journal of Medicine, 288, 564-570.

McIntosh, R. M., Griswold, W. R., Chernack, W. R., Williams, G., Strauss, J., Kaufman, D. B., Koss, M. N., McIntosh, J. R., Cohen, R., and Weil, R. (1975). Cryoglobulins III: Further studies on the nature, incidence, clinical, diagnostic, prognostic and immunopathologic significance of cryoproteins in renal disease. Quarterly Journal of Medicine, 44, 285-387.

McIntosh, R. M., Kaufman, D. B., Kulvinskas, C., and Grossman, B. J. (1970). Cryoglobulins I: The nature, incidence and clinical significance of cryoglobulins in glomerulonephritis. Journal of Laboratory and Clinical Medicine, 75, 566-677.

McIntosh, R. M., Kaufman, D. B., and Kulvinskas, C. (1971a). Cryoglobulins II: The biologic and chemical properties of cryoglobulins in acute poststreptococcal glomerulonephritis. International Archives of Allergy and Applied Immunology, 41, 700-715.

McIntosh, R. M., Kaufman, D. B., Kulvinskas, C. (1971b). Alterations of the chemical composition of human immunoglobulin $\mathrm{G}$ by Streptococcus pyogenes. Journal of Medical Microbiology, 4, 535-538.

McIntosh, R. M., Kaufman, D. B., McIntosh, J. R., and Griswold, W. R. (1972). Glomerular lesions produced in rabbits by autologous serum and autologous $\mathrm{IgG}$, treated with B hemolytic streptococcus. Journal of Medical Microbiology, 5, 1-7.

Michael, A. F., Jr., Drummond, K. M., Good, R. A., and Vernier, R. L. (1966). Acute poststreptococcal glomerulonephritis: immune deposit disease. Journal of Clinical Investigation, 45, 237-248.

Miller, J. J., III, Olds Arroyo, L., and Akasaka, T. (1977). Antiglubulins in juvenile rheumatoid arthritis. Arthritis and Rheumatism, 20, 729-735.

Rodriguez-Iturbe, B., Carr, R. I., Garcia, R., Allen, J. E., Rabideau, D., Rubio, L., and McIntosh, R. M. (1978). Acute poststreptococcal glomerulonephritis in Maracaibo, I. Studies on circulating immune complexes and immunoglobulins: Evidence for a circulating immune complex disease. Kidney International (in press).

Rossen, R. D., Rickaway, R. H., Reisberg, M. A., Singer, D. B., Schloeder, F. X., Suki, W. N., and Eknoyan, G. (1977). Renal localization of antiglobulins in glomerulonephritis and after renal transplantation. Arthritis and Rheumatism, 20, 947-963.

Seegal, B. C., Andres, G. A., Hsu, K. C., and Zabriskie, J. B. (1965). Studies on the pathogenesis of acute and progressive glomerulonephritis in man by immunofluorescein and immunoferritin techniques. Federation Proceedings, 24, (Part I), 100.

Sheagren, J. N., Tuazaon, C. U., and Padmore, N. (1970). Rheumatoid factor in acute bacterial endocarditis. Arthritis and Rheumatism, 19, 887-890.

Skrifvars, B., Tallquist, G., and Tornroth, T. (1973). Renal involvement in essential cryoglobulinemia. Acta Medica Scandinavica, 194, 229-235.

Treser, G., Ahmed, U., and Rodriquez-Iturbe, B. (1974). Studies on the probable antigen of acute poststreptococcal glomerulonephritis. Kidney International, 6, 107A (abstract).

Yoshizawa, N., Treser, G., Sagel, I., Ty, A., Ahmed, U., and Lange, K. (1973). Demonstration of antigenic sites in glomeruli of patients with acute streptococcal glomeru-

i lonephritis by immunofluorescein and immunoferritin techniques. American Journal of Pathology, 70, 131-142.

Zabriskie, J. B., Utermohlen, V., Read, S. E., Fischeti, V. A. (1973). Streptococcus related glomerulonephritis. Kidney International, 3, 100-104.

Zinneman, M. M., Levi, D., and Seal, U. S. (1968). On the nature of cryoglobulins. Journal of Immunology, 100, 594-603.

Zubler, R. H., Nydegger, U., and Perrin, L. H. (1976). Circulating and intra-articular immune complexes in patients with rheumatoid arthritis. Journal of Clinical Investigation, 57, 1308-1319. 